\title{
Study on Authenticity of Teachers' Discourse in English Class
}

\author{
Xinxin Chen \\ Foreign Language Department, Qiqihar Medical University, Qiqihar 161000, Heilongjiang Province, China
}

Keywords: English teachers; teachers' discourse in classroom; English class; authenticity

\begin{abstract}
English is a linguistic subject. The key point of English teaching lies in cultivating students' English literacy and improving their abilities of listening, speaking, reading and writing. Due to the teaching requirements and characteristics of linguistic disciplines, English teachers' discourse in class has an important impact on the quality of English teaching. The discourse used by English teachers in the classroom plays an important role in organizing teaching, and it is also an important language input for students. In the classroom, students' direct contact with English is the language of English teachers. Therefore, it is necessary to ensure the authenticity of English teachers' discourse in the classroom. The authenticity of teachers' discourse in English class is conducive to bringing students into English situations, making students speak English more realistic and natural, and stimulating students' English learning ability. This paper mainly discusses how to increase the authenticity of teachers' discourse in English class and the effect of authenticity of teachers' discourse in English class on students' English learning. The authenticity of teachers' discourse in English class can be examined from three perspectives, that is, situational authenticity, linguistic authenticity and content authenticity.
\end{abstract}

\section{Introduction}

Teachers' discourse in classroom is the main method for teachers to implement teaching methods, especially for language subjects. Teachers' language in classroom is the main embodiment of teaching methods. English teachers' language in classroom has a direct impact on students' English learning quality and efficiency. And it to a certain extent reflects the teacher's teaching ability, teaching ideas and ideas. The discourse used by teachers in the classroom can not only serve as a medium to transfer knowledge to students, but also affect their learning methods to a certain extent, their learning efficiency and their ideological concepts. The authenticity of teachers' language in classroom is the teaching quality that teachers must possess in English teaching. So the study of the authenticity of teachers' discourse in English classroom is an important project to improve the quality of English teaching and to study teachers' teaching ability.

At present, some domestic educators have done some research on the role of authenticity of teachers' language in English classroom. Because it has a great impact on the quality of English classroom teaching and the improvement of students' English quality, it has become a hot topic in the field of education. Teachers' direct use of English to communicate with students in English class plays a positive role in English classroom teaching in China and can increase the role of English in teaching. In this way, English can be used as both the target language of teaching and the medium language of teaching. What's more, teachers can not only inculcate English as knowledge to students, but also make it play a role in organizing the teaching process.

\section{Situational authenticity of English teachers' classroom discourse}

The authenticity of language situations in English classroom has a great influence on students' practical English knowledge. Since the main purpose of English classroom is education rather than social intercourse, there are unique communicative principles and traditions in English classroom. There are many differences between this communicative approach and the social norms in real society. However, teachers should take full account of the actual communicative situation and the organic combination of needs in creating English communicative situations to ensure that the 
teaching situation in English classroom can not only impart practical English knowledge, but also make it accord with the characteristics of the teaching classroom. This requires teachers to provide personal feedback on the content of students' speeches rather than the accuracy of language forms when they interact with students in classroom situational teaching. This kind of communication is more conducive to putting the interactive discourse on the track of real communication than simple communication, rather than simply correcting and practicing language. The authentic language interaction scenarios can train students' English ability and reaction ability in actual communication, which is more conducive to improving students' English quality than the simple language form training.

\section{Linguistic authenticity of English teachers' classroom discourse}

The authenticity of English teachers' classroom discourse refers to the language used by teachers in the classroom which has practical significance and function. The ultimate goal of language teaching should not be to enable students to achieve higher scores in written tests and neglect students' ability to actually listen to and speak English. Moreover, English teachers' use of meaningful and useful words in class has many advantages for students' English learning.

\subsection{Being prepare students for real communication in the future}

The ultimate goal of language discipline is to be able to use it in real life. The authenticity of the English teacher's discourse in the classroom directly determines whether the students can contact the English knowledge of practical significance and function in the first time. If the teacher uses the authenticity of the discourse in the classroom teaching, the students will be able to immerse themselves in a lot of daily learning in the cumulative process of classroom learning. The use of authentic discourse in the classroom by English teachers can improve the students' knowledge of oral English in daily communication and prepare them for practical English communication in their future life.

\subsection{Being conducive to motivate students' learning motivation}

The low initiative of students in English learning is one of reasons that hinder the improvement of students' English literacy. This is mainly because students can't understand the practicality of English in English learning. Especially in the Chinese background, there are very few students who can use English to communicate. In addition, English teaching in China is more focused on exam-oriented education. Among them, the written test scores account for a large proportion of English scores, which leads students to learn English more grammar and English sentence structure, and does not pay attention to the oral English knowledge and English pronunciation used in daily practical communication. Teachers can use the authentic English discourse in the classroom to create an English communication environment for students. It can make students not only feel that English learning is not boring reciting words and memorizing grammar, but also realize that English is a very useful language. Only when students are aware of the role of English can actively learn English. The authenticity of teachers' discourse in classroom is an important way to stimulate students to learn English.

\subsection{Being helpful for students to notice the changing language phenomenon}

One of the characteristics of linguistics is that it has different forms and meanings in different contexts. Changing language phenomena are one of the main characteristics of language science. However, in the traditional English teaching mode, teachers usually use Chinese to explain knowledge, and the English knowledge they teach is limited to the content of the textbook. The only way to train students' listening and speaking ability is to listen to English. Teachers can help students to listen to the paper and carry out a short English conversation in class. This kind of English teaching method can neither let the student experience the unceasing change language phenomenon, nor let them realize the English language charm. The use of authentic English discourse in the classroom helps students to notice the changing language phenomena, and authentic 
language materials can reflect the changing phenomena in the language. The changing phenomena of the language need students to contact authentic contexts for a long time to realize. Therefore, The authenticity of teachers in classroom discourse is very necessary in English teaching.

\section{Conclusion}

At present, many English teachers haven't realized the importance of using authentic English discourse in classroom for teaching quality and efficiency. Some teachers have realized the importance of using authentic English in class, but in the actual teaching process. It may be due to objective teaching conditions, or perhaps due to personal English literacy factors, teachers can not always adhere to the use of authentic English language teaching in the classroom. However, some English teachers who try to use authentic discourse in the classroom may lack authenticity because of lack of experience. If the communicative situation lacks authenticity, the discourse will also lack authenticity.

Or some teachers simply consider the explanation of language knowledge, and the English used in class is not authentic enough. Some languages are seldom used in real life, or even do not exist at all. It is hoped that the discussion on the authenticity of teachers' discourse in English class will promote the concern and discussion of the colleagues in the educational circles.

\section{Acknowledgements}

The research in this paper was supported by Heilongjiang Provincial Education Science Planning Project: A Study of the Effectiveness of Teacher Talk in College English Class from the Perspective of Speech Act Theory (NO. GBD1317151)

\section{References}

[1] Luxin. Investigation and Research on Interaction in College English Classroom of University [J]. Journal of Anhui Electronic Information Vocational and Technical College, No. 04, 2011.

[2] Gong Changhua. Application of Chinese Register Prediction in Listening Teaching [J]. Journal of Anhui University of Technology (Social Sciences), 2002.

[3] Hu Yongjin, Zhang Yanling. Translation of Extended Anaphora and Textual Anaphora and Its Implications for Foreign Language Teaching [J]. Anhui Literature (second half month), 2010-01.

[4] Zhang Xiaoqin, Lu Zongli. English Majors' Exercise Analysis Based on Evaluation Theory [J]. Journal of Anhui Institute of Science and Technology, No. 05, 2011.

[5] Wang Dongping. Structure and Classification of "Task" in Task-based Foreign Language Teaching Method [J]. Journal of Anqing Normal University (Social Science Edition), 2003.

[6] Wang Huiping. Critical Discourse Analysis and Teaching of English Reading [J]. Journal of Anqing Normal University (Social Science Edition), No. 12, 2010.

[7] Wu Lilin and Zhang Linzhi. Analytical Hierarchy Process of College English Teaching Preferences from the Perspective of Learning Style [J]. Journal of Baoding University, 2005.

[8] Ding Wei. Earliest Set of Phonograph Films in China-- The Phonograph Film of the Chinese Accent Published by China Book Company [J]. Editorial Friend , 2009, 2011. 